\title{
Peningkatkan Kemampuan Sosial Anak Melalui Permainan Jamuran
}

\author{
Amallia Putri Fitriani \\ STKIP Modern Ngawi \\ Jl. Ir. Soekarno (Ring Road Barat) Kabupaten Ngawi \\ mayu28455@gmail.com \\ Putri Ayu Maharani \\ STKIP Modern Ngawi \\ Jl. Ir. Soekarno (Ring Road Barat) Kabupaten Ngawi \\ ampufitri@gmail.com
}

\begin{abstract}
Abstrak
Tujuan kajian ini adalah untuk mengetahui dan memahami peran permainan jamuran dalam meningkatkan kemampuan sosial anak. Hal tersebut juga berguna sebagai sarana melestarikan permainan tradisional dan menginspirasi kegiatan pembelajaran di luar ruangan untuk guru Pendidikan Anak Usia Dini (PAUD). Metode penelitian yang digunakan adalah menggunakan metode studi kepustakaan (library research). Hasil kajian menyatakan bahwa permainan adalah hal yang sangat penting bagi anak, terutama dalam meningkatkan keterampilan sosial. Permainan jamuran penuh dengan nilai-nilai tradisi yang dimainkan secara kelompok kurang lebih 10 orang. Tingginya nilai tradisi dari permainan jamuran dan memiliki potensi untuk meningkatkan keterampilan sosial anak merupakan hal yang menjadi fokus utama permainan ini perlu dilestarikan. diharapkan pendidik dapat menerapkan permainan jamuran untuk menstimulasi seluruh aspek perkembangan anak, terlebih pada kemampuan sosial anak dan agar anak mengetahui sedikit tentang permainan jaman dahulu yang harus dilestariakn kembali.

Kata Kunci: Permainan, Sosial, Jamuran
\end{abstract}

\section{PENDAHULUAN}

Anak usia dini secara umum adalah anakanak di bawah usia 6 tahun. Pemerintah melalui UU Sisdiknas nomor 20 tahun 2003, mendifinisikan anak usia dini adalah anak dengan rentang usia 0-6 tahun. Sedangkan menurut NAEYC anak usia dini ialah anak yang berusia $0-8$ tahun. Anak-anak di usia ini adalah usia masa emas anak atau disebut juga golden age. Dimasa ini, merupakan masa penting bagi anak dimana pertumbuhan dan perkembangan anak harus diperhatikan. Anak-anak di usia ini mudah sekali meniru apa yang mereka lihat, cepat tanggap. Pada usia ini pula, anak-anak memiliki enam aspek perkembangan yakni aspek nilai agama dan moral, kognitif, fisik-motorik, bahasa, sosial emosional, dan seni yang harus diasah dan di kembangkan.

Melalui Pendidikan Anak Usia Dini, anak-anak mendapatkan pelayanan berupa pemberian rangsangan untuk mrmbantu pertumbuhan dan perkembangan jasmani dan rohani, agar berkembang secara optimal, guna membentuk pribadi berkarakter dan memiliki kesiapan untuk kehidupan selanjutnya. Salah satu aspek perkembangan yang juga perlu di kembangkan dalam era melenial adalah 
aspek sosial. Perkembangan sosial adalah perolehan kemampuan berperilaku yang sesuai dengan tuntutan sosial menjadi orang yang mampu bermasyarakat memerlukan 3 proses, diantaranya belajar berperilaku yang dapat diterima secara sosial, memainkan peran sosial yang dapat diterima dan perkembangan sosial (E. B. Hurlock, 1995). Pendapat lain menyatakan perkembangan sosial ialah perkembangan perilaku anak dalam menyesuaikan diri dengan aturan- aturan masyarakat dimana anak itu berada (Masitoh \& Setiasih, 2007). Perkembangan sosial diperoleh anak melalui kematangan dan kesempatan belajar dari berbagai respon terhadap dirimya. Berdasarkan beberapa pendapat, secara umum perkembangan sosial ialah kemampuan yang harus dicapai anak dalam hal berperilaku, bersosialisasi dan berinteraksi langsung terhadap masyarakat dan lingkungan sekitar, yang sesuai dengan aturan-aturan bermasyarakat, agar anak mampu menghadapi kehidupan selanjutnya.

Dengan melakukan aktifitas permainan, selain meningkatkan kemampuan sosial anak, dapat juga meningkatkan kreatifitas anak, mampu menumbuhkan rasa percaya diri karena pada saat anak bermain, anak tidak sendiri secara tidak sengaja anak mau tidak mau harus berinteraksi dengan teman lain, tampil di depan umum, mampu meluapkan emosi yang berlebih pada anak. Secara umum, konsep bermain dan permainan berbeda. Bermain ialah suatu kegiatan yang dilakukan berulang-ulang, spontan dan menyenangkan tanpa memikirkan hasil akhir. Sedangkan permainan adalah suatu kegiatan yang menyenangkan yang dilaksanakan untuk kepentingan kegiatan itu sendiri. Permainan memiliki ciri-ciri sebagai yakni adanya seperangkat peraturan yang eksplisit yang mesti dipatuhi oleh para pemain serta adanya tujuan yang harus dicapai pemain atau tugas yang mesti dilaksanakan (Hidayat, 1980: 5). Pendapat lain menyatakan permainan sebagai suatu aktifitas yang membantu anak mencapai perkembangan yang utuh, baik fisik, intelektual, sosial, moral, dan emosional (Freeman \& Munandar, 1996). Secara umum permainan adalah suatu kegiatan menyenangkan yang dilakukan oleh beberapa anak dengan aturan-aturan yang harus dipatuhi para pemain, dengan tujuan membantu anak mencapai perkembangan yang positif untuk anak.

Kemampuan sosial anak perlu ditanamkan pada setiap anak. Banyak anak dengan keterampilan sosial rendah, mereka cenderung tidak memiliki teman, cenderung minder dan tertutup. Dengan menanamkan kemampuan sosial sejak dini, diharapkan anak mampu berinteraksi dengan lingkungan, anak lebiih menyatakan diri, berani mengungkapkan setiap perasaan dan berani tampil di muka umum. Aktivitas permainan dapat menjadi solusi untuk menigkatkan sosial pada anak.Berbagai penelitian menyebutkan bahwa bermain mempunyai manfaat yang besar bagiperkembangananak.Bermain merupakan pengalaman belajar yang berguna untuk anak. Bermain mempunyai beberapa manfaat yakni Mengembangkan aspek fisik Bermain merupakan wahana untuk mengembangkan fisik. Bermain memberikan kesempatan untuk mengembangkan gerakanhalus dan kasar. (2) Mengembangkan aspek sosial. Aspek sosial anak seperti sikap sosial, komunikasi,mengorganisasi peran, dan interaksi dengan sesama teman akanberkembang melalui permainan. (3) 
Mengembangkan aspek emosi. Bermain merupakan media untuk mengekspresikan pikirandan perasaan.Saat kegiatan permainan, anak dapat mengendalikan emosinya, menyalurkan keinginannya, dan menerapkan disiplin dengan menaati peraturan. (4) Mengembangkan aspek kognisi. Bermain bagi anak berfungsi untuk mempermudah perkembangan kognisi anak. Anak berkomunikasi dengan anak lain sehingga perbendaharaan katanya menjadi lebih banyak (Tedjasaputra, 2001). Bermain simbolik juga dapat meningkatkan kognisi anak untuk dapat berimajinasi menuju berpikir abstrak. Dengan kata lain, manfaat dari permainan yakni meningkatkan kemampuan sosial emosional anak, menumbuhkan rasa percaya diri pada anak, memperkaya kosa kata bahasa, anak lebih aktif bergerak, menumbuhkan kreatifitas anak, anak mampu berfikir kongkrit dan mengasah kognitif anak. Tujuan kajian ini adalah untuk mengetahui dan memahami peran permainan jamuran dalam meningkatkan kemampuan sosial anak. Hal tersebut juga berguna sebagai sarana melestarikan permainan tradisional dan menginspirasi kegiatan pembelajaran di luar ruangan untuk guru Pendidikan Anak Usia Dini (PAUD). Lebih lanjut manfaat yang dapat ditarik dari kajian ini adalah meningkatnya kemampuan sosial anak dan kemampuan lain yang menyertainya serta mengenalkan permainan tradisional yang belum diketahui.

\section{METODE}

Metode penelitian yang digunakan adalah menggunakan metode studi kepustakaan (library research). Studi pustaka atau kepustakaan dapat diartikan sebagai serangkaian kegiatan yang berkenaan dengan metode pengumpulan data pustaka, membaca dan mencatat serta mengolah bahan penelitian (Zed, 2003). Penelitian kepustakaan harus memperhatikan langkah-langkah dalam meneliti kepustakaan, metode dalam mengumpulkan data, membaca dan mengelola bahan pustaka serta peralatan yang harus dipersiapkan dalam metode penelitian tersebut, agar memudahkan dalam mendapatkan data.

\section{HASIL DAN PEMBAHASAN}

\section{A. Kajian Kemampuan Sosial Anak Usia Dini}

Keterampilan sosial mempunyai makna sebagai kemampuan individu dalam mengungkapkan perasaan baik perasaan positif maupun perasaan negatif dalam hubungannya dengan orang lain tanpa kehilangan penguatan sosial dan dalam berbagai ragam hubungan dengan orang lain yang mencakup respon verbal dan non verbal (Bellack et al., 1979). Maka dalam kemampuan sosial anak dapat mengelola emosi dirinya dengan orang lain yang berkenan dengan hati dan kepedulian antar sesama manusia, sehingga anak dapat berinteraksi baik dengan teman sebaya, orang dewasa, maupun lingkungannya. Anak adalah pribadi yang unik dan melewati beberapa perkembangan kepribadian secara terus menerus, maka lingkungan yang diupayakan dan diinginkan oleh pendidik dan orang tua yang dapat memberikan kesempatan lebih banyak pada anak untuk bereksplorasi berbagai macam pengalaman dan suasana anak.

\section{B. Kajian Permainan}

Bermain dan permainan adalah hal yang sangat penting bagi anak. Bermain menjadikan salah satu cara pembelajaran untuk mememacu meningkatkan aspek- 
aspek bermain sesuai dengan pedoman pembelajaran terhadap anak usia dini, yakni belajar secara bermain dan bermain seraya belajar. Kegiatan yang dilakukan anak sepanjang hari karena bagi anak bermain adalah hidup dan hidup adalah bermain. Maka dari itu, pembelajaran yang diberikan kepada anak usia dini harus menyenangkan dan tidak membosankan. Pembelajaran yang menyenangkan dan tidak membosankan dapat dikemas melalui permainan. Permainan memberikan kelonggaran sesudah orang melakukan tugasnya sekaligus mempunyai sifat membersihkan. Permainan adalah sebaliknya bekerja. Artinya, Permainan ialah suatu aktifitas fisik yang menyenangkan untuk melatih aspek-aspek perkembangan, merefresh anak setelah melakukan rutinitas sehari-hari yang bertujuan untuk kesenangan anak dan sangat penting dalam kehidupan selanjutnya.

\section{Permainan dan Kemampuan Sosial Anak}

Anak usia dini identik dengan bermain karena dunia mereka adalah dunia bermain, dan dapat dikatakan bahwa pekerjaan dan hidup mereka ialah bermain. Melalui kegiatan bermain, orang tua maupun pendidik dapat mengajarkan anak dengan santai namun tetap menyenangkan bagi anak, yang bertujuan untuk meningkatkan aspek-aspek perkembangan pada anak, termasuk pada aspek perkembangan sosial dan emosional anak. Bermain sebagai sarana anak untuk bersosialisasi secara langsung dengan lingkungan sekitar. Dengan bermain, anak mengenal dan menghargai masyarakat, selain itu anak merasa punya harga diri karena merasa mampu menguasai tubuh, gerakan dan keterampilan sosial. Ada beberapa alasan anak perlu bermain diantaranya ialah karena dalam diri anak memliki energy yang lebih yang harus disalurkan, anak juga perlu melepaskan desakan emosi secara tepat melalui bermain. Jika energi dan emosi tersebut tidak disalurkan secara tuntas, maka akan berpengaruh pada kehidapan anak di kemudian hari. Selanjutnya, anak memerlukan penyegaran setelah melakukan rutinitas sekolah, anak berperan langsung dalam kehidupan bermasyarakat yang akan memberikan mereka pengalaman langsung untuk memperoleh dasar kehidupan sosial.

\section{Permainan jamuran}

Dewasa ini jarang sekali terlihat anak-anak bermain bersama teman sebayanya, terlebih untuk bermain permainan tradisional. Anak usia dini jarang ada yang mengenal permainan tradisional. Kebanyakan dari mereka bermain gawai, game online. Padahal sebenarnya ada banyak sekali permainan tradisional, contohnya: boy-boyan, lompat tali, petak umpet, engrang, bentengan, engklek, jamuran dan masih banyak lagi. Pada penelitian ini mengangkat salah satu permainan tradisional yakni jamuran. Banyak orang-orang yang belum mengetahui sejarah permainan jamuran, terlebih anak milenial saat ini.

Kilas balik tentang permainan jamuran yang umumnya dimainkan oleh anak-anak pedesaan yang berjumlah 10 orang atau lebih, dimana saat itu listrik belum ada di kehidupan masyarakat dan biasanya permainan ini dilakukakan pada malam hari terang bulan. Biasanya anakanak yang ikut bermain berusia 6-13 tahun. Jamuran yang berasal dari Pulau Jawa, dikreasikan oleh seorang ahli pendidik yang berjiwa demokratis yakni Sunan Giri yang juga salah satu tokoh sunan wali songo. Bukan hanya permainan 
jamuran saja yang beliau ciptakan, beliau mendidik dengan melalui bermacammacam permainan. Permaianan jamuran sendiri diciptakan dalam rangka untuk menyebarkan dakwahnya pada masa itu. Dakwah tersebut dimaksudkan dalam filosofi dari nama jamuran yang berasal dari kata jamur. Jamur merupakan tanaman yang tumbuh dan berkembang di tempat lembab. Terkadang jamur hanya diasumsikan sebagai tanaman pengganggu atau parasit, tetapi ada juga beberapa jenis jamur yang bermanfaat bagi kehidupan manusia. Maka dapat disimpulkan bahwa filosofi dari permainan jamuran tersebut sama halnya dengan kita sebagai manusia yang bermanfaat bagi orang lain tetapi bukan tidak mungkin kita menjadi pengganggu bagi pihak lain.

Tujuan Sunan Giri menciptakan permainan ini selain untuk kesenangan anak, juga ada nilai-nilai pendidikan yang diajarkan seperti kebersamaan atau bersosialisasi, ketanggaksan gerak sesuai dengan irama, kemampuan berekspresi hingga kemampuan memahami perintah. Makna dalam setiap permainan ini menggambarkan seseorang untuk saling bekerja sama dan peduli pada teman yang lain. Melalui permainan ini juga anak dapat menambah teman, dan sudah sepantasnya permainan anak ini harus dilestarikan dan dibangkitkan lagi dengan dikemas dengan format yang lebih menarik dan kreatif.

Untuk cara memainkan permainan jamuran, misal ada 10 orang yang bermain kemudian diundi dengan melakukan hompipa untuk menentukan siapa yang harus jaga. Yang kalah harus berada dilingkaran (boleh dengan posisi duduk maupun berdiri), dan yang menang akan membuat lingkaran besar dengan bergandengan tangan dan bernyayi sambil bergoyang kekanan dan kekiri. Berikut lagu permainan jamuran :

Jamuran ya gégéthok

Jamur apa ya gégéthok

Jamur gajih mbejijih sa ara-ara

Siram badhé jamur apa

Ketika sudah pada kalimat 'siro badhe jamur opo?', anak yang berada di tengah lingkaran lantas berteriak menyebut sebuah gerakan pura-pura yang wajib kami perbuat. Anak-anak lain yang semula bergandengan tangan membentuk lingkaran, lalu berhamburan. Untuk menirukan seperti apa yang di ucapkan anak yang kalah tadi. Misal 'jamur patung!', maka anak-anak bergegas menjadi patung. Diam tak bergerak. Tidak boleh tersenyum, tidak boleh tertawa meski digoda. Jika ada anak yang tertawa, tersenyum, atau yang bergerak akan terkena hukuman yaitu ia harus menggantikan posisi anak yang kalah tadi. Bila sudah ada yang terkena, lantas bermain lagi dari awal. Kemudian yang kena hukuman, masuk ke dalam lingkaran, lainnya bergandengan tangan melingkar dan mulai menembang jamuran, diulang dari semula.

Dalam permainan tradisional jamuran dapat mengembangkan beberapa aspek, yaitu fisik motorik, bahasa, seni, dan sosial emosional dalam diri anak. Untuk aspek fisik motorik pada permainan jamuran, yang anak dapatkan ketika anak saling bergandengan sambil berjalan dan berputar. Pada aspek bahasa, dapat dilihat ketika anak bercakap-cakap dengan permainan jamuran tentang apa yang anak pilih atau yang sesuai perintah pada aturan main. Sedangkan untuk seni pada permainan ini ketika semua anak menyanyikan lagu permaianan jamuran bersama-sama dengan gembira. Selain itu pada aspek sosial emosional dalam diri 
anak, anak pastinya akan beragumen, bekerjasama bagaimana supaya memenangkan permainan, bercakap-cakap dengan temannya, hal ini dapat mengembangkan komunikasi dan interaksi dengan teman lainnya.

\section{E. Kemampuan Sosial Anak}

Selain sebagai hiburan dan ajang permainan jamuran ternyata memiliki pengaruh besar terhadap prkembangan anak, salah satunya dapat membuat anakanak lebih bahagia, serta memiliki pengalaman masa kecil yang menyenangkan yang kelak dapat diceritakan pada generasi mereka selanjutnya. Permainan jamuran sendiri juga memiliki manfaat bagi perkembangan anak, yakni: (1) anak menjadi lebih kreatif, karena mereka menggunakan benda, barang-barang, atau tumbuhan yang ada disekitar para pemain.

mengembangkan kecerdasan musical anak, nyanyian atau bunyi-bunyian yang sangat akrab pada permainan jamuran, (3) mengembangkan kecerdasan kinestetik anak, pada umumnya dalam permainan jamuran akan mendorong anak untuk bergerak seperti melompat, berlari, berputar dan gerakan lainnya, (4) mengembangkan kecerdasan intelektual pada anak, permainan ini akan mengawali wawasan anak dalam ragam pengetahuan, (5) mengembangkan kecerdasan emosi antar personal anak, maka akan mengasah toleransi dan empati terhadap orang lain. Hasil riset menyatakan bahwa institusi sosial yang terbangun secara natural di masyarakat berpotensi untuk meningkatkan keberdayaan anggota masyarakat (Laksono, 2018).

\section{F. Peran Permainan Jamuran Dalam Kemampuan Sosial Anak}

Permainan tradisional jamuran merupakan permainan yang tepat untuk usia 4-13 tahun. Permainan tradisional jamuran merupakan permainan tradisional yang telah diturunkan dari generasi ke generasi berikutnyadimana kegiatan tersebut mengandung nilai-nilai kebudayaan serta terdapat aktivitas sosial terhadap sesama pemainnya (Zulfita, 1997). Lebih lanjut bahwa pola perilaku sosial yang berkembang pada masa kanakkanak yaitu, meniru, persaingan, kerjasama, simpati, empati, dukungan sosial, mau berbagi (E. B. Hurlock, 1995). Pola perilaku sosial ini dapat terstimulus melalui lingkungan sosial anak. Dengan permainan tradisional jamuran, mengasah anak untuk bersosialisasi dan berinteraksi dengan sesama. Perilaku anak yang dilakukan dapat diterima oleh teman maupun masyarakatsekitar di kehidupan anak selanjutnya. Misalnya dalam permainan ini, anak mau mematuhi aturan dalam main atau tidak. Jika anak mematuhinya dan bersikap sportif, maka teman-teman akan menerimanya, begitupun sebaliknya jika anak bertingkah semaunya sendiri dan tidak mematuhi aturn main, maka anak tersebut akan menjauhinya. Permainan tradisional jamuran membuat anak akan terlibat aktif dalam suatu kelompok bermain yang menimbulkan adanya interaksi kerjasama memahami aturan yang ada agar dapat diterima dalam suatu kelompok sosial. Kemampuan sosial yang terasah dengan baik sejak usia dini merupakan bekal sosialisasi yang baik di masa depan seorang anak diterimadalam masyarakat.Peran permainan jamuran juga mengasah rasa percaya diri pada anak. Karena ketika anak mau bermain dengan teman, maka disitulah anak berani tampil di depan umum.

\section{PENUTUP}




\section{Simpulan}

Bermain adalah suatu aktifitas yang dilakukan oleh anak secara terus-menerus, bersifat menyenangkan dan sebagai penyegar setelah melakukan rutinitas sehari-hari, tanpa paksaan ataupun tekanan dari luar. Bermain dapat dilakukan dengan melakukan permainan tradisional, misalnya permainan jamuran. Pada permainan jamuran mempunyai pengaruh besar pada aspek-aspek perkembangan anak, salah satunya pada kemampuan sosial anak. Fungsi permainan ini menjadikan anak lebih berani tampil di depan umum, berinteraksi langsung terhadap lingkungan sosial, mendapatkan pengalaman langsung untuk memperolah dasar kehidupan sosoial, belajar memahami dan memainkan peran yang ada disekitarnya, mengerti dan memecahkan masalah.

\section{Saran}

Penerapan permainan tradisional seperti permainan jamuran dapat meningkatkan kemampuan sosial pada anak, diharapkan pendidik dapat menerapkan permainan jamuran untuk menstimulasi seluruh aspek perkembangan anak, terlebih pada kemampuan sosial anak dan agar anak mengetahui sedikit tentang permainan jaman dahulu yang harus dilestariakn kembali. Tentunya pendidik dapat mengemas permainan jamuran dengan lebih kreatif lagi agar lebih menarik untuk anak.

\section{DAFTAR PUSTAKA}

Bellack, A. S., Hersen, M., \& Lamparski, D. (1979). Role-play tests for assessing social skills: Are they valid? Are they useful? Journal of Consulting and Clinical Psychology, 47(2), 335-342. https://doi.org/10.1037/0022006X.47.2.335

E. B. Hurlock. (1995). Perkembangan Anak (I). Erlangga.

Freeman, J., \& Munandar, U. (1996). Cerdas dan Cemerlang: Kiat Menemukan Bakat Anak Usia 0-5 tahun. PT. Gramedia Pustaka Utama.

Laksono, B. A. (2018). The Community Empowerment Through Social and. Jurnal Pendidikan Humaniora, 6(3), 115-122.

Masitoh, \& Setiasih, O. (2007). Strategi pembelajaran $T K$. Universitas Terbuka.

Tedjasaputra, M. S. (2001). Bermain, Mainan, dan Permainan Untuk Pendidikan Usia Dini. Grasindo.

Zed, M. (2003). Metode peneletian kepustakaan. Yayasan Obor Indonesia.

Zulfita, E. (1997). Pembinaan Nilai-Nilai Budaya Melalui Permainan Rakyat. Lazuardi Indah. 